\title{
DETERMINATION OF RAINWATER HARVESTING TANK SIZE
}

\author{
TSIHRINTZIS V.A. ${ }^{1 *}$ \\ BALTAS E. ${ }^{2}$
}

\author{
${ }^{1}$ Centre for the Assessment of Natural Hazards and Proactive Planning \\ and Laboratory of Reclamation Works and Water Resources Management \\ Department of Infrastucture and Rular Development \\ School of Rular and Surveying Engineering \\ National Technical University of Athens \\ ${ }^{2}$ Department of Water Resources and Environmental Engineering \\ School of Civil Engineering \\ National Technical University of Athens
}

Received: 05/01/2014

Accepted: 25/10/2014

Available online: 11/11/2014 *to whom all correspondence should be addressed: e-mail: tsihrin@central.ntua.gr

\section{ABSTRACT}

Onsite rainwater harvesting is an inexpensive water source for indoor use; it is also a sustainable water management practice, since it may contribute to the reduction of runoff volume and peaks, and to the control of non-point source pollution. The aim of this paper is to provide a method for sizing rainwater harvesting tanks based on the local daily rainfall record, the served family size, the roof collection area, the roof type, the in-house water uses, and other factors. Various methods used worldwide are presented and compared. The comparative application of these methods is made using a daily rainfall record from a meteorological station near Kimmeria Village in Xanthi, Northeast Greece. Based on the proposed method here, the optimum tank size is computed by allowing excess water to overflow and setting to zero the use of the public water supply; the method may result in reduced tank sizes compared to other methods tested.

Keywords: rainwater harvesting; tank sizing; Rippl method; water budget

\section{Introduction and background}

In most areas of the world, the available water supplies have not increased over the last century, or actually, they may have decreased in several cases due to pollution. The population and human needs are continuously increasing, and the climatic change is expected to result in a temperature increase and rainfall reduction in certain parts of the world, including the Mediterranean countries (IPCC, 2007). As a result, an unbalance is expected between water supplies and demands, which will further worsen in the coming years; therefore, all sources of water should be considered in the future.

Rainwater harvesting, i.e., the collection and storage of rainwater for potable or non-potable in-house uses, is a relatively inexpensive method to reduce consumption of potable water supplied by public sources; it also presents as a sustainable water management practice, since it may contribute to the reduction of runoff volumes and peaks (of course this assumes that the tank is empty which may not be the case during the entire rainy season), and the consequent reduction of required storm sewer sizes, and to the reduction of the size of public water supply systems (Australian Government, 2004). Cost figures and benefits of rainwater harvesting systems are discussed extensively in various publications (e.g., Australian Government, 2004). 
Untreated harvested rainwater can be used for non-potable uses, such as toilet flushing, clothe washing, other household uses, garden irrigation, etc., while potable uses are also common in several countries (e.g., Australia), but they may require appropriate treatment of harvested rainwater, depending on its quality. In general, depending on final use, caution should be employed to avoid public health risks.

As a water management practice, rainwater harvesting is quite old, dating long before the advent of today's public water systems; for example, it was a standard practice in the Minoan civilization (ca. 3200-1100 BC) in ancient Greece, but also elsewhere in the world (e.g., the Indus river at Mohenjo-Daro and Harappa; ca. 3300-1300 BC) (Angelakis et al., 2005; Antoniou et al., 2012). This practice continued and the technology was further improved during the Hellenistic period ( $c a .323-67 \mathrm{BC}$ ), the Roman period (ca. 67 BC - 330 AD), and the Byzantine period (ca. 330 - 1204 AD) (Antoniou et al., 2012).

Today, an effort is made to promote rainwater harvesting. Several publications address water harvesting, including among others: (1) system description and design in several parts of the world and for various uses of harvested rainwater (e.g., Cheng and Hong, 2004; Villarreal and Dixon, 2005); (2) quality of harvested rainwater and health risk assessment (e.g. Villarreal and Dixon, 2005; Sazakli et al., 2007; Melidis et al., 2007; Ahmed et al. 2010; Rouvalis et al., 2009; Vialle et al., 2011; Farreny et al., 2011; Gikas and Tsihrintzis, 2012); (3) sizing of rainwater harvesting storage tanks (which is also the aim of this paper) and computation of potable water savings (e.g., Eroksuz and Rahman, 2010; Abdulla and Al-Shareef, 2009; Slys, 2009; Ghisi, 2010; Aladenola and Adeboye, 2010; Imteaz et al., 2011; Souza and Ghisi, 2012).

Methods for sizing the rainwater harvesting tank vary from country to country. For example, in the UK, the BS 85152009 Code of Practice is used, which states that the capacity of the rainwater harvesting storage tank must be the least of either $5 \%$ of the annual rainwater yield (ARY) or $5 \%$ of the annual rainwater demand (ARD) (http://oasis-rainharvesting.co.uk/ sizing the tank). Larger tanks are not allowed, because of the risk of bacteria breeding which may cause health hazards. The annual rainwater yield (ARY) $[L]$ is computed as:

$A R Y=C \bar{P} A$

where $\mathrm{C}$ is the drainage factor (i.e., the runoff coefficient) which accounts for rainfall losses at the collection surface and usually takes values between 0.8 (for slate or stone) and 0.9 (for tile), i.e., it depends on the roof cover material; $\bar{P}$ is the mean annual rainfall depth of the tank area [mm]; and $A$ is the rain collection area $\left[\mathrm{m}^{2}\right]$.

The ARD [L] is usually calculated considering non-potable uses only (i.e., washing machine, flushing tank, garden irrigation), as follows (http://oasis-rainharvesting.co.uk/ sizing the tank):

$A R D=16,000 N_{\text {cap }}+60 A_{G}$

where $N_{\text {cap }}$ is the number of capita in the residence, and $A_{G}$ is the garden area $\left[\mathrm{m}^{2}\right]$. Thus, the required tank storage volume $\mathrm{V}_{\text {tank }}[\mathrm{L}]$ is:

$\mathrm{V}_{\text {tank }}=0.05 \min (A R Y, A R D)$

Alternatively, the tank size can be computed to store water for a number of days with no rain $\left(N_{d d}\right)$, usually taken as $\mathrm{N}_{\mathrm{dd}}=21$ days in the UK (www. RainWaterHarvesting.co.uk). In this case:

$\mathrm{V}_{\text {tank }}=\min (A R Y, A R D)\left(N_{d d} / 365\right)$

In Australia, the ARY is computed based on a $\mathrm{C}$ of 0.80 to 0.85 . In addition, the rainfall $\bar{P}$ is reduced by a parameter $\mathrm{I}_{\mathrm{a}}[\mathrm{mm}]$ to account for initial abstraction of the collection area. Recommended values for $\mathrm{I}_{\mathrm{a}}$ are $2 \mathrm{~mm} / \mathrm{mo}$ or $24 \mathrm{~mm} / \mathrm{yr}$ (Australian Government, 2004). Therefore:

$A R Y=C\left(\bar{P}-I_{a}\right) A$

The annual demand is computed based on the number of persons served $\mathrm{N}_{\text {cap }}$ and the daily per capita water consumption q [L/capita/d], as follows: 
$A R D=365 \mathrm{~N}_{\text {cap }} \mathrm{q}$

The tank size is then calculated for each month using the average monthly rainfall of the area based on mass balance of inflow and demand, assuming an empty tank at the beginning (Australian Government, 2004), and considering that there is overflow when, in any month, computed storage exceeds the volume of the storage tank, and there is no supply from the tank when the demand exceeds the water in storage. Alternatively, the tank size determination can be based on satisfying the demand for the maximum number of dry days.

In Germany, rainwater harvesting is regulated by DIN 1989 (2002). For sizing of the storage tank, rainfall data for at least 10 years are recommended. A minimum daily consumption of $q=20 \mathrm{~L} / \mathrm{capita} / \mathrm{d}$ should be used to compute the mean annual demand from the tank (Eq. 6). Assuming a dry period of four months, then a simple method to compute the required tank storage is (http://www.rainwaterconference.org/uploads/media/Rainwater Harvesting - an overview .pdf):

$\mathrm{V}_{\text {tank }}=(4 / 12)$ ARD

However, supply depends on rainfall input which should be taken into account. It is proposed to prepare a graph of cumulative monthly roof runoff $\left[\mathrm{m}^{3}\right]$ over a one-year period and of cumulative water demand $\left[\mathrm{m}^{3}\right]$ as function of month (i.e., the Rippl diagram) (http://www.rainwaterconference.org/uploads/media/Rainwater Harvesting - an overview .pdf). The greatest vertical deviation between these two lines provides the required size of the storage $\operatorname{tank}\left[\mathrm{m}^{3}\right]$.

Finally, in the State of Virginia, USA, the tank size is computed based on ARY (Eq. 1) and ARD (Eq. 6) (The Cabel Brand Center, 2007).

\section{Materials and methods}

\subsection{Rainfall data}

The rainfall data used in this study were collected at the meteorological station of the Laboratory of Ecological Engineering and Technology, Department of Environmental Engineering, Democritus University of Thrace. This station is located on campus near Kimmeria Village, Xanthi, Greece $\left(41^{\circ} 08^{\prime} 46.80^{\prime \prime} \mathrm{N} ; 24^{\circ} 55^{\prime} 09.66^{\prime \prime} \mathrm{E}\right)$. The time step of recording was $5 \mathrm{~min}$. The record spanned from October 1, 2003 to September 30, 2012. The data was manipulated to provide daily rainfall depth, which was easier to handle. All computations were performed in Microsoft Excel.

\subsection{First computation method}

Based on the record, the mean annual precipitation $\bar{P}[\mathrm{~mm}]$ can be computed as:

$\overline{\mathrm{P}}=\frac{365}{\mathrm{~N}} \sum_{\mathrm{t}=1}^{\mathrm{N}} \mathrm{P}_{\mathrm{t}}$

where $P_{t}[\mathrm{~mm}]$ is the measured rainfall depth of any day (time $t[d]$ ), and $N$ is the number of daily data points (here $N=3271$ ). The daily runoff depth $R_{t}[\mathrm{~mm}]$ at time $t[\mathrm{~d}]$ can be computed from the rainfall using the runoff coefficient $C$ of the rain collection area, e.g., roof area $(C=0.9)$ :

$R_{t}=C P_{t}$

The cumulative runoff $\Sigma R_{t}[\mathrm{~mm}]$ at time $t$ can be computed on a daily basis as follows:

$\Sigma \mathrm{R}_{\mathrm{t}}=\Sigma \mathrm{R}_{\mathrm{t}-1}+\mathrm{R}_{\mathrm{t}}$

and the corresponding cumulative runoff volume at time $t$, which is the cumulative inflow volume $\Sigma I_{t}$ $\left[\mathrm{m}^{3}\right]$ to the storage tank:

$\Sigma I_{\mathrm{t}}=10^{-3} \sum \mathrm{R}_{\mathrm{t}} \mathrm{A}$

where $A$ is the rain collection area $\left[\mathrm{m}^{2}\right]$. 
The water demand $D_{t}$ in the residence at time $t$ depends on the number of capita $N_{\text {cap }}$, the daily per capita water use q (in Greece, q=150 to $180 \mathrm{~L}$ /capita/d), and the percent $\mathrm{p}$ of total use which will be satisfied by harvested rainwater. The maximum value of parameter $p$, among other factors, depends mainly on mean annual rainfall, collection area size and number of capita served, i.e., a storage tank may not be able to satisfy the entire annual water demand, but there may be an upper limit on how much of the annual water demand can be satisfied, according to these three main factors. If rainwater is to be used for non-potable uses, then the maximum value for $p$ will be between $40 \%$ and $55 \%$, excluding garden irrigation. Therefore:

$D_{t}=N_{\text {cap }} q(p / 100)$

The cumulative outflow from the storage tank at any time $t$ will be:

$\Sigma \mathrm{O}_{\mathrm{t}}=\Sigma \mathrm{O}_{\mathrm{t}-1}+\mathrm{D}_{\mathrm{t}}$

By plotting the difference $\Delta=\Sigma \mathrm{I}_{\mathrm{t}}-\Sigma \mathrm{O}_{\mathrm{t}}$ as function of time (modified Rippl diagram), the required tank size to store all water, with no water overflowing at any time, can be computed as the maximum of differences between a highest value and any lowest value that follows this highest (Gupta, 1989), i.e.:

$V_{\text {tank, max }}=\max \left(\Sigma I_{t}-\Sigma O_{t}\right)-\min \left(\Sigma I_{t+n}-\Sigma O_{t+n}\right)$

with $n>0$.

\subsection{Second computation method}

The previous method, which stores the entire runoff without any overflow, may result in a very large tank, which may have two possible problems: (1) it may be impractical to install, due to space limitations and cost; and (2) there is increased risk of bacteria breeding over time. The following method can be used instead.

The daily difference in inflow (runoff) and outflow (demand) is computed using Eqs. (9) and (12), as follows:

$\Delta \mathrm{S}_{\mathrm{t}}=\mathrm{C} \mathrm{P}_{\mathrm{t}} \mathrm{A}-\mathrm{N}_{\text {cap }} \mathrm{q}(\mathrm{p} / 100)$

Then, the water volume at any day $\mathrm{t}$ that could be stored in the tank without considering the tank size is computed as follows:

$\mathrm{S}_{\mathrm{t}}=\mathrm{S}_{\mathrm{t}-1}+\Delta \mathrm{S}_{\mathrm{t}}$

The computation is iterative and starts from an initial value $S_{0}$ at time $t=0$ (i.e., initial stored water in the tank). This can be any value, the most conservative being zero, which implies that the tank is initially empty, or alternatively, the tank can be considered full (i.e., $\mathrm{S}_{0}=\mathrm{V}_{\text {tank }}$ ) or partially full. To account for tank size when computing stored water in the tank at any day $t$, the following algorithm can be used iteratively in a time step-by-time step calculation:

if $\left[\mathrm{S}_{\mathrm{t}-1}+\Delta \mathrm{S}_{\mathrm{t}}>0\right]$ then $\left[\mathrm{S}_{\mathrm{t}}=\mathrm{S}_{\mathrm{t}-1}+\Delta \mathrm{S}_{\mathrm{t}}\right]$ else $\left[\mathrm{S}_{\mathrm{t}}=0\right]$

If $\mathrm{V}_{\text {tank }}$ is the tank capacity, the actual available stored water volume $\mathrm{S}_{\mathrm{t} \text { tank }}$ in the tank at day $\mathrm{t}$ results from the following algorithm:

if $\left[\mathrm{S}_{\mathrm{t}} \geq \mathrm{V}_{\text {tank }}\right]$ then $\left[\mathrm{S}_{\mathrm{t}, \text { tank }}=\mathrm{V}_{\text {tank }}\right]$ else $\left[\mathrm{S}_{\mathrm{t} \text {,tank }}=\mathrm{S}_{\mathrm{t}}\right]$

The volume of water $\mathrm{O}_{t}$ that overflows from the tank when the tank is full can be computed from the following algorithm:

if $\left[\mathrm{S}_{\mathrm{t}} \geq \mathrm{V}_{\text {tank }}\right]$ then $\left[\mathrm{O}_{\mathrm{t}}=\mathrm{S}_{\mathrm{t}}-\mathrm{V}_{\text {tank }}\right]$ else $\left[\mathrm{O}_{\mathrm{t}}=0\right]$

The water $T_{t}$ needed to be delivered from the public water supply to satisfy needs that would otherwise be satisfied by the tank if it contained adequate water volume can be computed as follows (this does not include the percentage 100-p of the demand - see Eq. (12) - which is always satisfied by public water supply): 
if $\left[S_{t, \text { tank }}>D_{t}\right]$ then $\left[T_{t}=0\right]$ else $\left[T_{t}=D_{t}-S_{t, \text { tank }}\right]$

These and the previous methods can be easily applied in a spreadsheet, assuming that the daily rainfall record (a minimum 10-year record is recommended) for the area where the tank will be located is available.

\section{Results}

\subsection{Calculations based on the dry days and annual rainfall}

Figure 1 presents the daily rainfall depth $\mathrm{P}_{\mathrm{t}}$ of the 10-year record used in the study. Rainfall depths varied from 0.0 to a maximum of $102.8 \mathrm{~mm}$ (February 5, 2012). The mean annual rainfall depth $\bar{P}$ (Eq. 8) was $687.1 \mathrm{~mm}$.

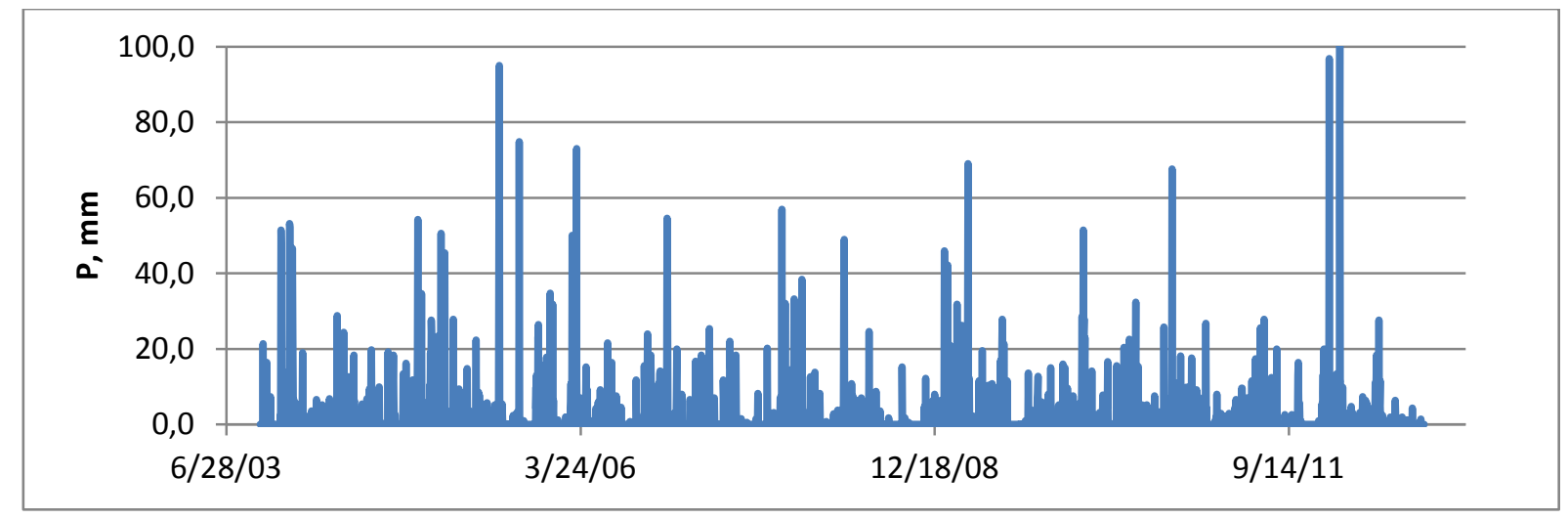

Figure 1. The rainfall depth record used in the calculation (Kimmeria station, Xanthi)

The maximum dry period (i.e., period without any rainfall) was 50 days (October 18, 2011 to December 6 , 2011). Figure 2 presents an analysis of days without rain. It was based on counting the maximum number of days without rain over the rainfall record. As a minimum dry period was set that of 5 days which occurred 159 times during the 10-year record. The 5-day dry period selection implies that at minimum there will always be stored water of about $1500 \mathrm{~L}$ with $p=50 \%(=150 \mathrm{~L} /$ capita/d $\times 4$ capita $\times 5 \mathrm{~d}$ $x$ 0.5), i.e., a min tank size of $1500 \mathrm{~L}$ for $\mathrm{N}_{\text {cap }}=4$ capita or an equivalent for smaller $\mathrm{N}_{\text {cap }}$ should be used. As an example, the figure shows that there were at least 13 time intervals with 20 or more days without rain or $8.18 \%$ of the 159 dry period occurrences. If one wanted to minimize the percentage of occurrence to about $5 \%$, then the dry period would be 23 days. This means that if the tank is sized to have water for 23 dry days, then this can cover $95 \%$ of dry periods. To maximize this coverage to about $99 \%$, then the dry period should be 43 to 50 days. According to these, Table 1 presents typical tank size calculations according to the storage for a 23 - or 50-day dry period, $q=150 \mathrm{~L} / \mathrm{capita} / \mathrm{d}$, and $\mathrm{p}=40 \%$, using the following equation:

$\mathrm{V}_{\text {tank }}=\mathrm{N}_{\mathrm{dd}} \mathrm{q} \mathrm{N}_{\text {cap }}(\mathrm{p} / 100)$

Table 1. Required tank size (L) to address a 23- or 50-day period without rain

\begin{tabular}{ccccccc}
\hline \multirow{2}{*}{$\begin{array}{c}\text { Percent of time the } \\
\text { tank has water }\end{array}$} & $\begin{array}{c}\text { Period without } \\
\text { any rainfall, } \mathbf{d}\end{array}$ & \multicolumn{5}{c}{ Tank size (L) for No. of persons served } \\
\cline { 3 - 7 } & 23 & $\mathbf{1}$ & $\mathbf{2}$ & $\mathbf{3}$ & $\mathbf{4}$ & $\mathbf{5}$ \\
\hline $95 \%$ & 50 & 1,725 & 3,450 & 5,175 & 6,900 & 8,625 \\
\hline $99 \%$ & 3,750 & 7,500 & 11,250 & 15,000 & 18,750 \\
\hline
\end{tabular}




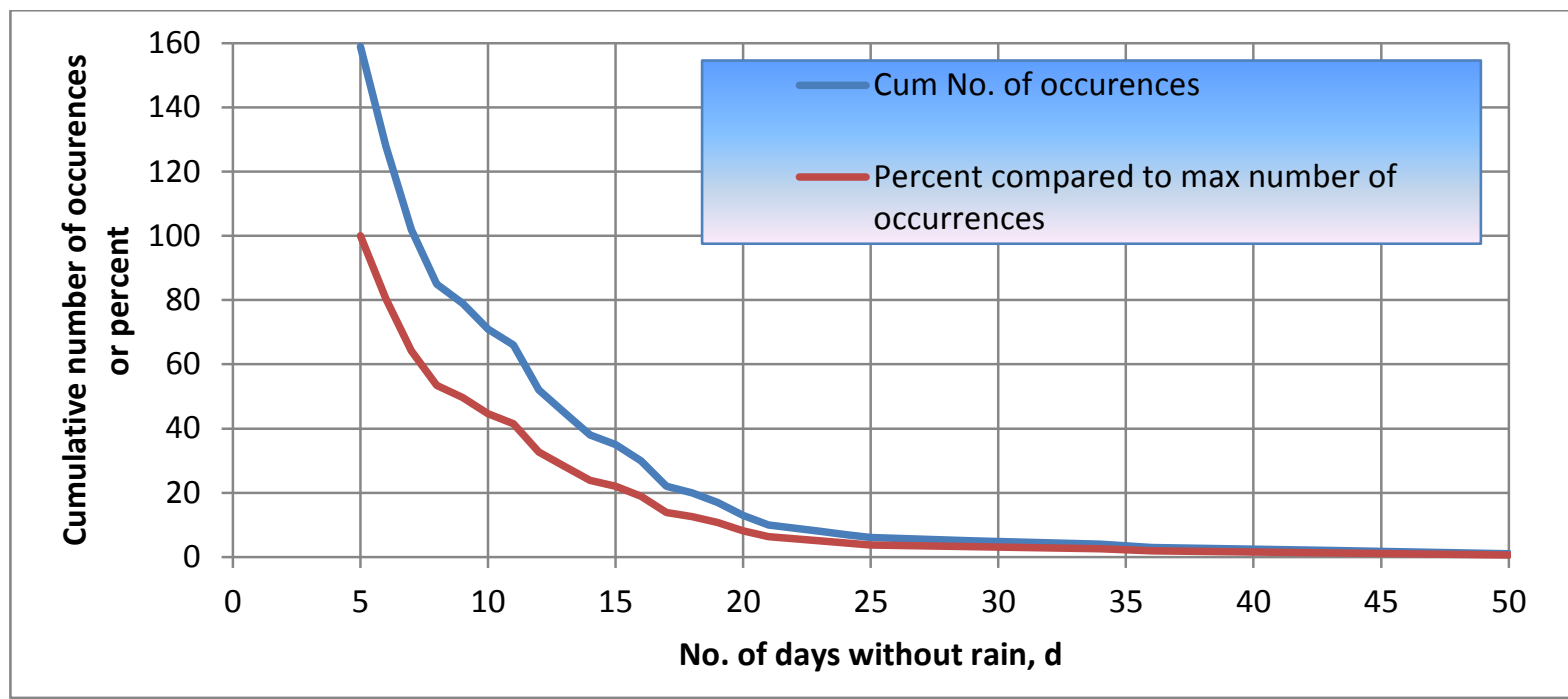

Figure 2. Cumulative number of occurrences and relative percentage as function of dry days.

Figure 3 presents the required roof collection area as function of the percentage $p$ of the total water consumption and the number of persons served. For these computations, ARY and ARD are balanced and predicted by Eqs. (1) and (12) multiplied by $365 \mathrm{~d}$, respectively, using $C=0.9, \bar{P}=687.1 \mathrm{~mm}$ and $\mathrm{q}=150$ L/capita/d, i.e.:

$A=\left[\left(\frac{365}{100}\right)\left(\frac{q}{C \bar{P}}\right)\right] N_{\text {cap }} p$

The figure presents the maximum percentage of the ARD that can be covered, assuming adequate tank storage capacity, for a certain roof size and number of people served.

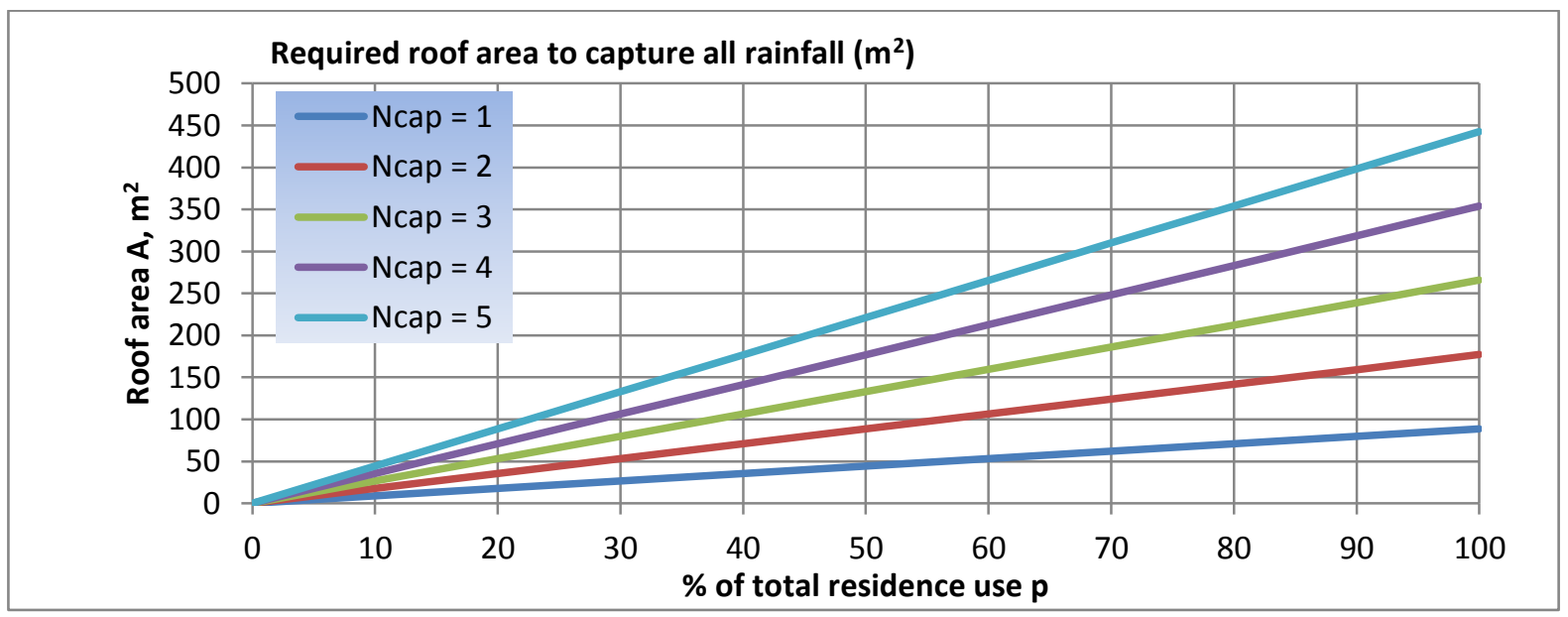

Figure 3. Required roof area to satisfy a certain percentage $p$ of the household water demand as function of the number of persons (computations for $\mathrm{C}=0.9, \mathrm{q}=150 \mathrm{~L} / \mathrm{capita} / \mathrm{d}, \bar{P}=687.1 \mathrm{~mm}$ ).

\subsection{First computation method}

Figure 4 presents the cumulative inflow minus cumulative outflow volume difference $\Delta=\Sigma \mathrm{I}_{\mathrm{t}}-\Sigma \mathrm{O}_{\mathrm{t}}$ in a storage tank based on Eqs. (11) and (13). Equation (14) is then used to compute the required capacity of the tank. As shown in Figure 4, the maximum difference $\Delta$ occurs on March 15, 2006 and is $81132 \mathrm{~m}^{3}$, the minimum occurs on December 15, 2011 and is $-9720 \mathrm{~m}^{3}$, and therefore, the required storage capacity according to Eq. (14) is $90852 \mathrm{~m}^{3}$. The computation was based on: a roof collection area $A=177.0 \mathrm{~m}^{2}, C=0.9, N_{\text {cap }}=5, q=150 \mathrm{~L} / \mathrm{capita} / \mathrm{d}$ and $\mathrm{p}=40 \%$. Note that $\mathrm{A}$ and $\mathrm{p}$ are in agreement with Figure 3 , implying that adequate rain water is available. 


\subsection{Second computation method}

Typical results of the method described in Section 2.3 are presented in Figure 5. The input data were the following: $A=177.0 \mathrm{~m}^{2}, C=0.9, N_{\text {cap }}=5, q=150 \mathrm{~L} /$ capita/d, $p=40 \%$, tank size $V_{\text {tank }}=50000 \mathrm{~L}$, initial storage in tank $=50000 \mathrm{~L}$. Figure $5 \mathrm{a}$ shows that the $50000 \mathrm{~L}$ capacity tank contains water for most time during the period of record and there are only three time periods when it dries up. The overflow volume variation with time is shown in Figure $5 \mathrm{~b}$. Overflow periods are limited. The maximum overflow during the record is $8359 \mathrm{~L}$ (March 12, 2006). Finally, Figure 5c presents the cumulative volume of water used from the public water supply, which is $47102 \mathrm{~L}$ for the whole period of record. This volume depends on the initial volume of the tank and becomes $53710 \mathrm{~L}$ if the computations are carried out assuming an initially empty tank. The use of public water supply occurs a few times during the period. The more severe cases are those starting on October 12, 2007, August 1, 2008 and November 22, 2011 (Figure 5c), which correspond to dates when the tank gets empty (Figure 5a). To totally avoid use of public water supply, the required tank volume is $93771 \mathrm{~L}$ assuming an initially full tank. However, this tank volume is adequate for a minimum initial volume of water in the tank down to $11024 \mathrm{~L}$.

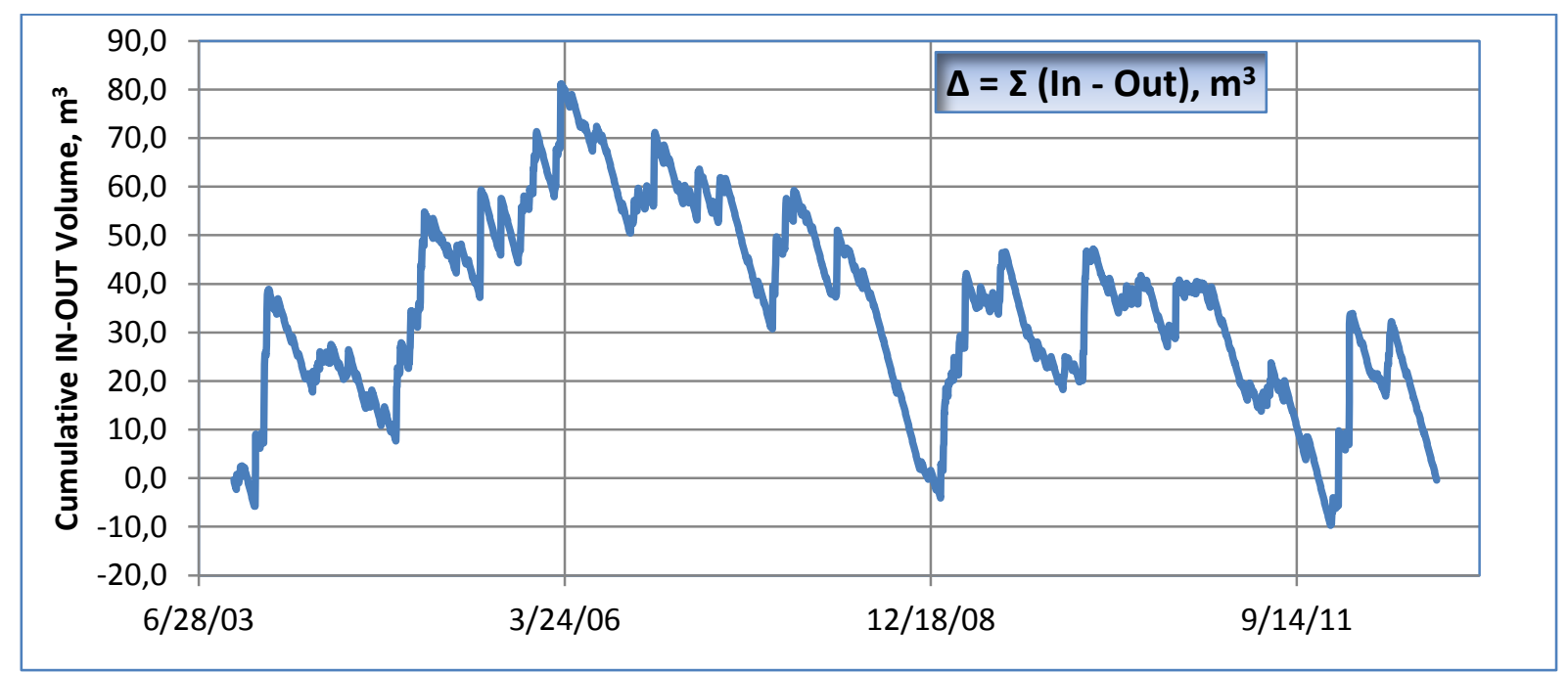

Figure 4. Difference between cumulative inflow and outflow from the tank (computations for $A=177.0$ $\mathrm{m}^{2}, \mathrm{C}=0.9, \mathrm{~N}_{\text {cap }}=5, \mathrm{q}=150 \mathrm{~L} /$ capita $/ \mathrm{d}$ and $\mathrm{p}=40 \%$ ).

The method allows for minimizing the tank size. This can be done using an optimization algorithm, for example "Goal Seek" in Microsoft Excel. The required tank capacity is the one which makes zero the use of public water supply (for given $A, C, N_{\text {cap }}, q$ and $p$ ). Figure 6 presents the optimum tank size as function of the roof area $A$ ( $A$ is related to $p$ through Figure 3 ), assuming that the tank is initially full. $A$ linear regression line is also fit through the data, presenting a nearly perfect determination coefficient $R^{2}$ (0.9993):

$\mathrm{V}_{\text {tank,opt }}=0.5195 \mathrm{~A}$

The figure also presents the minimum required initial water stored in the tank $\mathrm{S}_{0}$ for Eq. (20) to hold. This initial storage is given by the following equation, which also has an excellent determination coefficient $R^{2}(0.9960)$ :

$\mathrm{S}_{0}=0.0597 \mathrm{~A}$

In Eqs. (20) and (21), the optimum volume $V_{\text {tank,opt }}$ and the minimum initial volume $S_{0}$ are in $\mathrm{m}^{3}$. The equations can be used to predict the optimum tank size $V_{\text {tank,opt }}(L)$ as function of the rain collection area $A\left(m^{2}\right)$, considering indirectly the percent of total use $p$ (through Figure 3 ). These equations are not universal but depend on the rainfall record used (here: University station in Kimmeria, Xanthi), and values for parameters $\mathrm{C}=0.9$ and $\mathrm{q}=150 \mathrm{~L} / \mathrm{capita} / \mathrm{d}$. 

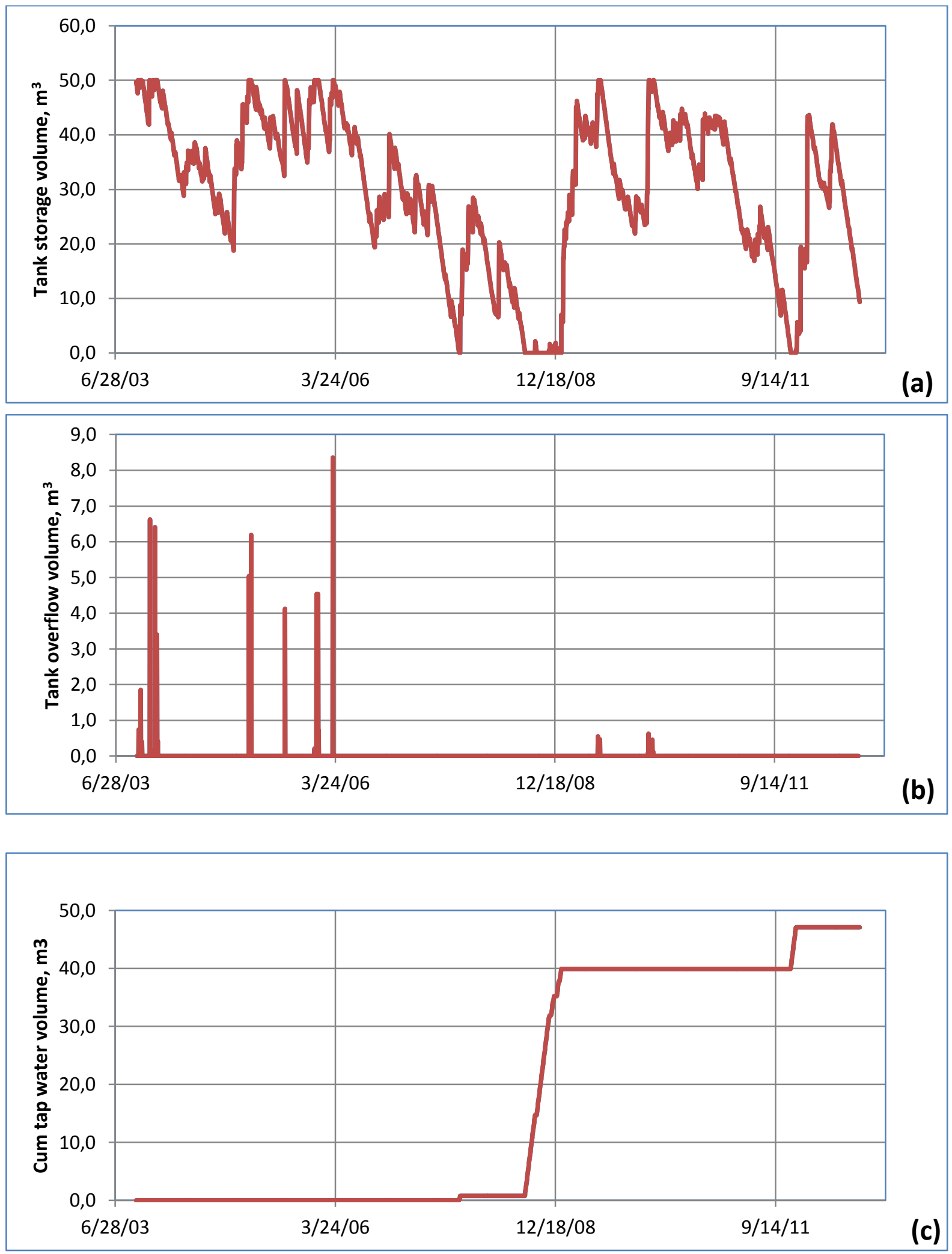

Figure 5. Computed actual storage volume in tank (a); overflow volume (b); and volume from public water supply (c). Computations for $A=177.0 \mathrm{~m}^{2}, C=0.9, \mathrm{~N}_{\text {cap }}=5, q=150 \mathrm{~L} /$ capita/d, $p=50 \%$, tank size $\mathrm{V}_{\text {tank }}$ $=50000 \mathrm{~L}$, initial storage in tank $=50000 \mathrm{~L}$. 


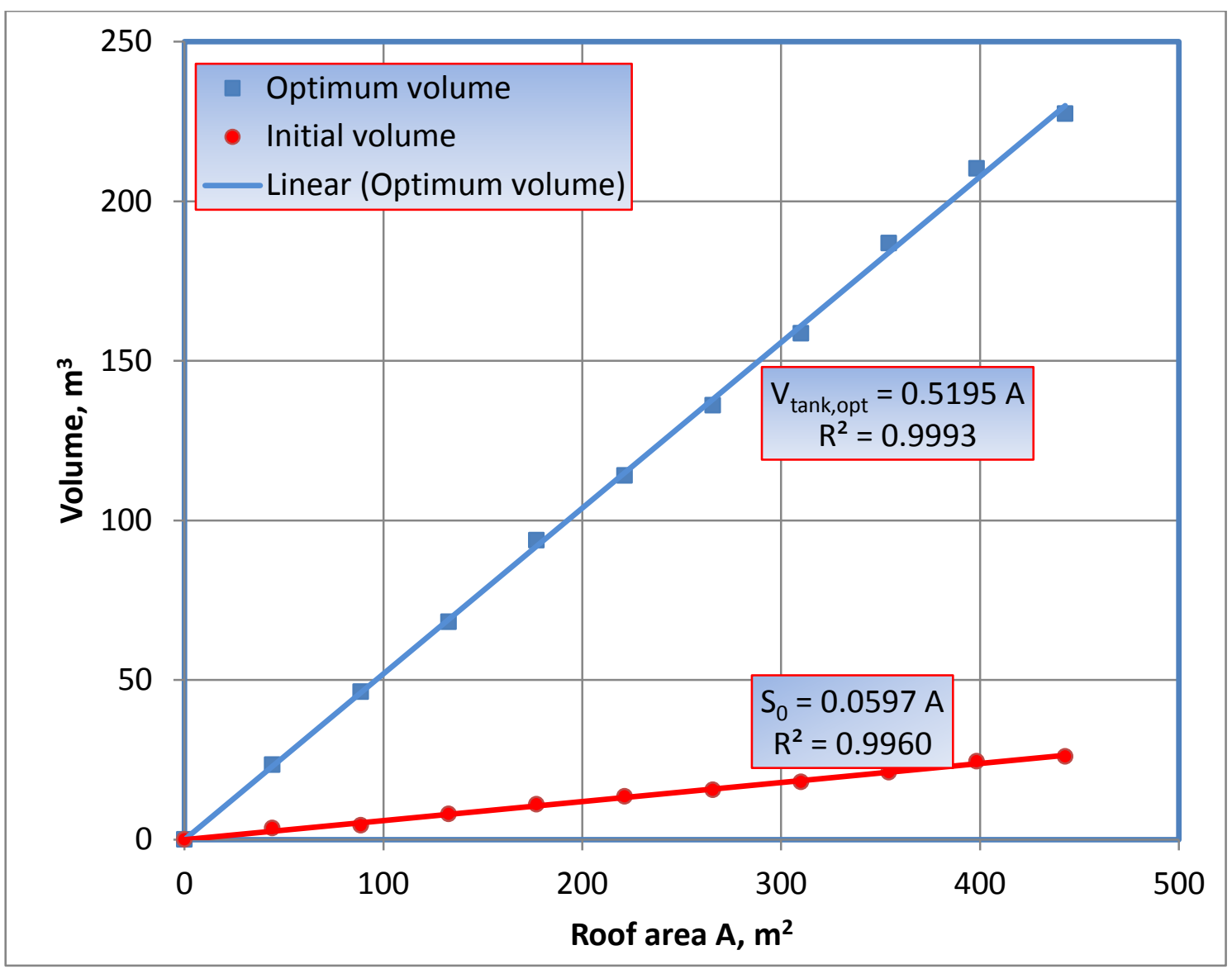

Figure 6. Optimum tank size and minimum initial storage as function of roof area

\section{Conclusions}

Various methods have been tested and a method is proposed for efficiently sizing rainwater harvesting tanks for in-house water use to cover part of the total need. The optimum tank size is computed by allowing excess water to overflow and setting to zero the use of the public water supply. The proposed method may result in reduced tank sizes compared to other methods tested.

\section{Acknowledgements}

An initial version of this manuscript was presented at the 13th International Conference on Environmental Science and Technology, CEST2013, Athens, Greece, 5-7 September 2013 (http://cest2013.gnest.org), Paper \# 652.

\section{References}

Abdulla F.A. and Al-Shareef A.W. (2009), Roof rainwater harvesting systems for household water supply in Jordan, Desalination, 243(1-3), 195-207.

Ahmed W., Vieritz A., Goonetilleke A. and Gardner T. (2010), Health risk from the use of roof-harvested rainwater in Southeast Queensland, Australia, as potable or nonpotable water, determined using quantitative microbial risk assessment, Appl. Environ. Microbiol., 76(22), 7382-7391.

Aladenola O.O. and Adeboye O.B. (2010), Assessing the potential for rainwater harvesting, Water Resour Manage., 24(10), 2129-2137.

Australian Government. (2004). Guidance on Use of Rainwater Tanks, ISBN 0642824436 Publication approval number 3432(JN8304).

Angelakis A.N., Koutsoyiannis D. and Tchobanoglous G. (2005), Urban wastewater and stormwater technologies in ancient Greece, Water Res., 39, 210-220. 
Antoniou G., Kathijotes N. and Angelakis A.N. (2012), Historical development of the technologies on rainwater harvesting in the Hellenic Civilization, The $3^{\text {rd }}$ IWA-RWHM Conference \& Exhibition, 20-24 May 2012, Goseong, Korea.

Cheng C.L. and Hong Y.T. (2004), Evaluating water utilization in primary schools, Build. Environ., 39, 837-845.

DIN 1989-1. (2002). Rainwater Harvesting Systems - Part 1: Planning, Installation, Operation and Maintenance. German Institute for Standardisation, Berlin, 2002.

Eroksuz E. and Rahman A. (2010), Rainwater tanks in multi-unit buildings: A case study for three Australian cities, Res. Conserv. Recycl., 54, 1449-1452.

Farreny R., Morales-Pinzon T., Guisasola A., Taya C., Rieradevall J. and Gabarrell X. (2011), Roof selection for rainwater harvesting: quantity and quality assessments in Spain, Water Res., 45, 3245-3254.

Ghisi E. (2010), Parameters influencing the sizing of rainwater tanks for use in houses, Water Resour Manage., 24(10), 2381-2403.

Gikas G.D. and Tsihrintzis V.A. (2012), Assessment of water quality of first-flush roof runoff and harvested rainwater, Journal of Hydrology, 466-467, 115-126.

Gupta R.S. (1989) Hydrology and Hydraulic Systems, Prentice Hall, New Jersey, USA, pp. 448-451.

Imteaz M.A., Shanableh A., Rahman A. and Ahsan A. (2011), Optimisation of rainwater tank design from large roofs: a case study in Melbourne, Australia, Res. Conserv. Recycl., 55, 1022-1029.

IPCC (2007) “Climate Change 2007: Impacts, Adaptation and Vulnerability" Contribution of Working Group II to the Fourth Assessment Report of the Intergovernmental Panel on Climate Change M.L. Parry, O.F. Canziani, J.P. Palutikof, P.J. van der Linden and C.E. Hanson (Eds) Cambridge University Press, Cambridge, UK.

Melidis P., Akratos C.S., Tsihrintzis V.A. and Trikilidou E. (2007), Characterization of rain and roof drainage water quality in Xanthi, Greece, Environ Monit. Assess., 127, 15-27.

Rouvalis A., Karadima C., Zioris I.V., Sakkas V.A., Albanis T. and Iliopoulou-Georgudaki J. (2009), Determination of pesticides and toxic potency of rainwater samples in western Greece, Ecotoxicol. Environ. Saf., 72, 828-833.

Sazakli E., Alexopoulos A. and Leotsinidis M. (2007), Rainwater harvesting, quality assessment and utilization in Kefalonia Island, Greece, Water Res., 41, 2039-2047.

Slys D. (2009), Potential of rainwater utilization in residential housing in Poland, Water Environ. J., 23, 318-325.

Souza E.L. and Ghisi E. (2012), Potable water savings by using rainwater for non-potable uses in houses, Water, 4, 607-628.

The Cabell Brand Center. (2007). Virginia Rainwater Harvesting Manual, Salem VA, www.cabellbrandcenter.org.

Vialle C., Sablayrolles C., Lovera M., Jacob S., Huau M.-C. and Montrejaud-Vignoles M. (2011), Monitoring of water quality from roof runoff: interpretation using multivariate analysis, Water Res., 45, 3765-3775.

Villarreal E.L. and Dixon A. (2005), Analysis of a rainwater collection system for domestic water supply in Ringdansen, Norrköping, Sweden, Build. Environ., 40, 1174-1184. 